\title{
PPARG wt Allele
}

National Cancer Institute

\section{Source}

National Cancer Institute. PPARG wt Allele. NCI Thesaurus. Code C51710.

Human PPARG wild-type allele is located in the vicinity of 3p25 and is approximately 146 $\mathrm{kb}$ in length. This allele, which encodes peroxisome proliferator-activated receptor gamma protein, plays a role in adipocyte differentiation. The gene has been implicated in the pathology of numerous diseases including obesity, diabetes, atherosclerosis and cancer. Mutations in the gene can lead to type 2 insulin-resistant diabetes, hypertension, obesity, colon cancer, familial partial lipodystrophy type 3 and carotid intimal medial thickness 1. 